\title{
Correction to: The impact of perennial allergic rhinitis with/without allergic asthma on sleep, work and activity level
}

Mercedes Romano ${ }^{1 *}$, Stephanie James ${ }^{2}$, Emily Farrington ${ }^{2}$, Richard Perry ${ }^{2}$ and Lisa Elliott ${ }^{1}$

\section{Correction to: Allergy Asthma Clin Immunol (2019) 15:81 https://doi.org/10.1186/s13223-019-0391-9}

The original version of this article [1] unfortunately included an error to an author's name and citation.

The first and corresponding author was unfortunately presented as Mercedes Rodriguez Romano. The correct author name is Mercedes Romano.

The correct author name has been included in the author list of this Correction article.

\section{Author details}

${ }^{1}$ ALK, Bøge Alle 1, 2970 Hørsholm, Denmark. ${ }^{2}$ Adelphi Values, Macclesfield, UK.

Published online: 05 February 2020

\section{Reference}

1. Romano M, James S, Farrington E, Perry R, Elliott L. The impact of perennial allergic rhinitis with/without allergic asthma on sleep, work and activity level. Allergy Asthma Clin Immunol. 2019;15:81. https://doi. org/10.1186/s13223-019-0391-9.

\section{Publisher's Note}

Springer Nature remains neutral with regard to jurisdictional claims in published maps and institutional affiliations.

The original article can be found online at https://doi.org/10.1186/s1322 3-019-0391-9.

*Correspondence: mrrdk@alk.net

${ }^{1}$ ALK, Bøge Alle 1, 2970 Hørsholm, Denmark

Full list of author information is available at the end of the article

(c) The Author(s) 2020. This article is licensed under a Creative Commons Attribution 4.0 International License, which permits use, sharing, adaptation, distribution and reproduction in any medium or format, as long as you give appropriate credit to the original author(s) and the source, provide a link to the Creative Commons licence, and indicate if changes were made. The images or other third party material in this article are included in the article's Creative Commons licence, unless indicated otherwise in a credit line to the material. If material is not included in the article's Creative Commons licence and your intended use is not permitted by statutory regulation or exceeds the permitted use, you will need to obtain permission directly from the copyright holder. To view a copy of this licence, visit http://creativeco mmons.org/licenses/by/4.0/. The Creative Commons Public Domain Dedication waiver (http://creativecommons.org/publicdomain/ zero/1.0/) applies to the data made available in this article, unless otherwise stated in a credit line to the data. 